\title{
Infection-triggered autoimmunity
}

\section{The case of herpes simplex virus type 1 and anti-NMDAR antibodies}

Russell C. Dale, MRCP, and Margherita Nosadini, MD

Neurol Neuroimmunol Neuroinflamm 2018;5:e471. doi:10.1212/NXI.0000000000000471

The recent paradigm that autoimmune encephalitis is associated with autoantibodies that bind to conformational epitopes of cell surface antigens involved in neurotransmission has transformed the field of autoimmune neurology and created new biomarkers for the clinician to define treatable acquired neurologic conditions. In parallel, a growing armamentarium of immune therapeutic agents is becoming available. But fundamental questions remain, particularly "why does this happen?" There is cohort-derived evidence suggesting age and ethnic vulnerability and emerging evidence of HLA associations. ${ }^{1,2}$ Anti-NMDA receptor (NMDAR) encephalitis, which is defined by a characteristic clinical syndrome and the presence of CSF autoantibodies to the NR1 subunit of the NMDAR, is the most common autoimmune encephalitis. In anti-NMDAR encephalitis, many female adults have an ovarian teratoma that contains NMDAR-expressing neural tissue, providing a hypothetical example of "cross-reactive" autoimmunity between the NMDARs in the tumor and in the brain. However, large cohorts have shown that ovarian teratomas are very uncommon in pediatric patients, ${ }^{3}$ so what is the "trigger" of the loss of immune tolerance in young children? Some of these children have preceding herpes simplex type 1 (HSV1) encephalitis, a destructive highly inflammatory encephalitis that predominantly affects temporal lobes and surrounding structures. After recovery, approximately $20 \%$ of children with HSV1 encephalitis deteriorate with a "second phase" of encephalitis, this time with clinical features typical of anti-NMDAR encephalitis, including florid movement disorders and encephalopathy, associated with the emergence of anti-NMDAR antibodies. ${ }^{4-6}$ This clear example of HSV1 encephalitis inducing secondary anti-NMDAR encephalitis yielded the hypothesis that the inflammatory destruction of neural tissue with release of neural antigens into the surrounding brain, circulation and then lymphatic system, resulted in a reactivation of autoreactive lymphocytes against NMDAR antigens and production of pathogenic antiNMDAR antibodies.

However a new article, in this month's Neurology ${ }^{\circledR}$ Neuroimmunology and Neuroinflammation, strengthens the evidence for the alternative pathophysiologic mechanism between HSV1 and anti-NMDAR autoimmunity: namely that HSV1 infection increases the likelihood of developing anti-NMDAR encephalitis, possibly through "molecular mimicry," without the need for brain tissue destruction (i.e., without HSV1 encephalitis). ${ }^{7}$ Salovin et al. performed testing for previous HSV1 infection (immunoglobulin $\mathrm{G}[\mathrm{IgG}]$ serology) in stored serum samples from children with anti-NMDAR encephalitis (with typical clinical features and positive serum anti-NMDAR antibodies) with no clinical or radiologic evidence of HSV1 encephalitis. There were 2 cohorts, the first from Philadelphia and the second from Barcelona (combined mean age 9 years, range 1-17). They found statistically significant elevation of HSV1 IgG seropositivity in patients with anti-NMDAR encephalitis compared with controls in the Philadelphia cohort and the combined cohorts ( $49 \%$ vs $21 \%$ in the combined cohorts, $p=0.007$ ). It is important that they used hospital controls who were children with other neuroinflammatory disorders, which reduced the likelihood that the findings were due to nonspecific inflammatory associations and makes it more likely to be specific to anti-NMDAR encephalitis. Second, they ensured that

\author{
Correspondence \\ Prof. Dale \\ Russell.dale@health.nsw.gov.au
}

\section{RELATED ARTICLE}

Anti-NMDA receptor encephalitis and nonencephalitic HSV-1 infection

Page e458 
patients did not have IV immunoglobulin (IVIG) before serologic sampling, as IVIG may induce false-positive infectious serologic findings, given the polyclonal multidonor origins. Third, the patients were age matched with controls - this is very important, particularly with an extremely common infection such as HSV1, which has increasing seropositivity with increasing childhood age. As expected, the Barcelona control group, who were older, had higher HSV1 seropositivity. Fourth, the authors also measured IgG against 2 other very common viral infections in childhood, namely cytomegalovirus and Epstein-Barr virus, and found no difference between anti-NMDAR encephalitis patients and controls.

There were some weaknesses in this approach, partly related to the retrospective nature of the study. First, it would have been of interest to better understand the relationship of the timing of infection and production of anti-NMDAR antibodies, which could have been performed by measuring HSV1 IgM antibodies, and convalescent HSV1 IgG sampling. Similarly, there is no reporting of the time between onset of anti-NMDAR encephalitis and serum sampling or of the type and timing of preceding clinical HSV1 infection. Second, and acknowledged by the authors, there was no controlling for race or socioeconomic factors, which may influence HSV1 infection, as the presence of other children in the family, and housing overcrowding can influence the prevalence of common childhood infectious disease. Third, it is still plausible that HSV1 could induce a subclinical HSV1 encephalitis in some patients, which could be missed clinically or radiologically-proving HSV1 PCR negativity in CSF would have added to this study and strengthened the findings further. Indeed, the detection of "asymptomatic" positive CSF PCR for HSV1 in anti-NMDAR encephalitis patients has been reported and discussed in a recent review. ${ }^{6}$ Moreover, the number of patients in the Salovin study who fulfilled Graus et $\mathrm{al}^{8}$ clinical criteria for anti-NMDAR encephalitis is unclear. It is also unclear whether NMDAR antibodies were present in CSF (or only serum). Finally, although cytomegalovirus and Epstein-Barr virus testing helped understand the specificity of the HSV1 findings, testing for other infections, particularly Mycoplasma pneumoniae would have added to the study, as Mycoplasma has been proposed to trigger anti-NMDAR encephalitis, ${ }^{9}$ and other types of herpes viruses beside HSV1 have been reported in anti-NMDAR encephalitis. ${ }^{6}$
Regardless of these limitations, the article by Salovin et al. is important and redresses the balance in the debate about induction of anti-NMDAR autoimmunity and supports the hypothesis that preceding viral infection can result in loss of immune tolerance in predisposed individuals.

\section{Author contributions}

R.C. Dale: no duplicate publication; drafting/revising the manuscript; accepts responsibility for conduct of research and will give final approval; acquisition of data; and principal investigator/guarantor. M. Nosadini: no duplicate publication; drafting/revising the manuscript; analysis or interpretation of data; and accepts responsibility for conduct of research and will give final approval.

\section{Study funding}

No targeted funding reported.

\section{Disclosure}

R.C. Dale served on the scientific advisory board of National Blood Authority; received speaker honoraria from Biogen and Bristol-Myers Squibb; served on the editorial board of MSARD, Neurology: Neuroimmunology \& Neuroinflammation, and European Journal of Paediatric Neurology; and received research support from the NHMRC and Multiple Sclerosis Research Australia. M. Nosadini reports no disclosures. Full disclosure form information provided by the authors is available with the full text of this article at Neurology.org/NN.

\section{References}

1. Jones HF, Mohammad SS, Reed PW, et al. Anti-N-methyl-d-aspartate receptor encephalitis in Māori and Pacific Island children in New Zealand. Dev Med Child Neurol 2017;59:719-724.

2. Mueller SH, Färber A, Prüss H, et al. Genetic predisposition in anti-LGI1 and antiNMDA receptor encephalitis. Ann Neurol 2018;83:863-869.

3. Titulaer MJ, McCracken L, Gabilondo I, et al. Treatment and prognostic factors for long-term outcome in patients with anti-NMDA receptor encephalitis: an observational cohort study. Lancet Neurol 2013;12:157-165.

4. Armangue T, Leypoldt F, Málaga I, et al. Herpes simplex virus encephalitis is a trigger of brain autoimmunity. Ann Neurol 2014;75:317-323.

5. Mohammad SS, Sinclair K, Pillai S, et al. Herpes simplex encephalitis relapse with chorea is associated with autoantibodies to $\mathrm{N}$-methyl-D-aspartate receptor or dopamine- 2 receptor. Mov Disord 2014;29:117-122.

6. Nosadini M, Mohammad SS, Corazza F, et al. Herpes simplex virus-induced anti-N methyl-D-aspartate receptor encephalitis: a systematic literature review with analysis of 43 cases. Dev Med Child Neurol 2017;59:796-805.

7. Salovin A, Glanzman J, Roslin K, Armangue T, Lynch DR, Panzer JA. Anti-NMDA receptor encephalitis and nonencephalitic HSV-1 infection. Neurol Neuroimmunol Neuroinflamm 2018;90:xx-xxx.

8. Graus F, Titulaer MJ, Balu R, et al. A clinical approach to diagnosis of autoimmune encephalitis. Lancet Neurol 2016;15:391-404.

9. Florance NR, Davis RL, Lam C, et al. Anti-N-methyl-D-aspartate receptor (NMDAR) encephalitis in children and adolescents. Ann Neurol 2009;66:11-18. 


\title{
Neurology \\ Neuroimmunology \& Neuroinflammation
}

\author{
Infection-triggered autoimmunity: The case of herpes simplex virus type 1 and \\ anti-NMDAR antibodies \\ Russell C. Dale and Margherita Nosadini \\ Neurol Neuroimmunol Neuroinflamm 2018;5; \\ DOI 10.1212/NXI.0000000000000471
}

This information is current as of June 11, 2018

\section{Updated Information \& \\ Services}

References

Citations

Subspecialty Collections

Permissions \& Licensing

Reprints including high resolution figures, can be found at:

http://nn.neurology.org/content/5/4/e471.full.html

This article cites 9 articles, 0 of which you can access for free at: http://nn.neurology.org/content/5/4/e471.full.html\#\#ref-list-1

This article has been cited by 1 HighWire-hosted articles: http://nn.neurology.org/content/5/4/e471.full.html\#\#otherarticles

This article, along with others on similar topics, appears in the following collection(s):

Viral infections

http://nn.neurology.org//cgi/collection/viral_infections

Information about reproducing this article in parts (figures,tables) or in its entirety can be found online at:

http://nn.neurology.org/misc/about.xhtml\#permissions

Information about ordering reprints can be found online:

http://nn.neurology.org/misc/addir.xhtml\#reprintsus

Neurol Neuroimmunol Neuroinflamm is an official journal of the American Academy of Neurology.

Published since April 2014, it is an open-access, online-only, continuous publication journal. Copyright

Copyright $\odot 2018$ The Author(s). Published by Wolters Kluwer Health, Inc. on behalf of the American

Academy of Neurology.. All rights reserved. Online ISSN: 2332-7812.

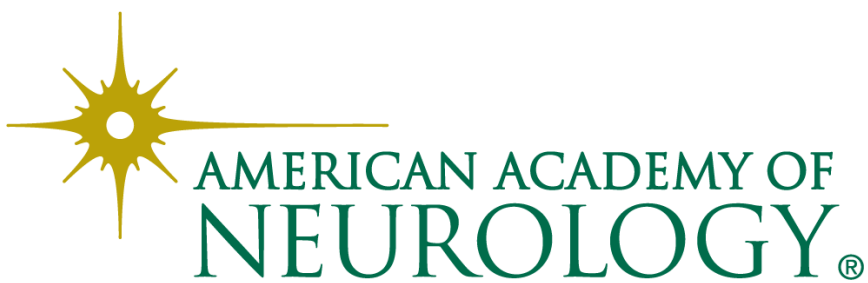

